December 2011

\title{
Diffusing Genocide Studies, Defusing Genocides
}

Adam Jones

Follow this and additional works at: https://digitalcommons.usf.edu/gsp

\section{Recommended Citation}

Jones, Adam (2011) "Diffusing Genocide Studies, Defusing Genocides," Genocide Studies and Prevention: An International Journal: Vol. 6: Iss. 3: Article 8.

Available at: https://digitalcommons.usf.edu/gsp/vol6/iss3/8

This Articles is brought to you for free and open access by the Open Access Journals at Digital Commons @ University of South Florida. It has been accepted for inclusion in Genocide Studies and Prevention: An International Journal by an authorized editor of Digital Commons @ University of South Florida. For more information, please contact digitalcommons@usf.edu. 


\title{
Diffusing Genocide Studies, Defusing Genocides
}

\author{
Adam Jones \\ University of British Columbia, Okanagan
}

In evaluating the state of the field of comparative genocide studies, this article explores themes such as the "return to Raphael Lemkin," evident in some recent works; scholarly investigations of the genocidal dynamic in Western colonialism and the parallels in Nazi depredations; and ongoing efforts to "resurrect" littleknown and forgotten genocides of the past. The growing pluralism and internationalization of genocide studies is acknowledged but contrasted with certain parochial features of the field, which endure. This article concludes with observations on the increasingly prominent role of genocide scholars in policy-making and humanitarian spheres.

Key words: genocide, comparative genocide studies, field, discipline, Holocaust

Genocide studies has never been more diffuse an enterprise. And rarely since its inception, if ever, has it been as exciting a field of inquiry. I offer here a few comments on the state of this rapidly evolving field, and try to isolate some present and medium-term trends.

The comparative study of genocide underwent something of an explosion in the first decade of the twenty-first century, particularly the period 2004-2008. A raft of excellent contributions appeared, both theoretically sophisticated and thematically diverse. Institutionally, the field not only widened but deepened, and it was rendered politically more complex by the appearance of the International Network of Genocide Scholars (INoGS). INoGS inherited the Journal of Genocide Research as its flagship to stand alongside the International Association of Genocide Scholars (IAGS) and its journal, Genocide Studies and Prevention, established in 2006, to which I am glad to contribute these words. Two distinguishable academic "circuits" have evolved around these organizations: IAGS's center of gravity is on the US east coast and in central Canada, ${ }^{1}$ while INoGS is anchored in the United Kingdom for Western Europe and Australasia. As an outlier in this scheme-based in Western Canada, and therefore mostly riding the IAGS circuit, but serving on the editorial board of the INoGS journal-I have come to appreciate the opportunity to bestride the institutional poles of genocide studies. But the field's division, which maps to some extent onto the scholarship, remains a division. Attempts to merge IAGS and INoGS broke down in 2010-2011, amidst some acrimony.

The occasional pettiness of such exchanges has in no way impeded the flood of intellectual contributions during recent years. A pair of essential works, Martin Shaw's What Is Genocide? (2007) and Mark Levene's Genocide in the Age of the Nation-State (two volumes so far, 2005), encapsulate major lines of interest and investigation in the field. ${ }^{2}$ Shaw's work presents the most nuanced portrait of genocide as social destruction-returning to the roots of the concept in Raphael Lemkin's work, and participating in a broader "return to Lemkin," a significant trend of recent 
years. ${ }^{3}$ I have expressed skepticism toward a concept of cultural genocide independent of mass killing, suggesting a couple of cases in which erosion of a group's identity or expulsion of its members, in the absence of a large-scale murderous component, seemed unlikely to qualify as genocidal. ${ }^{4}$ But Shaw's richly sociological vision of genocide, presented in a compact and clearly argued form, will resonate through the field in the coming years.

Levene's epic project, Genocide in the Age of the Nation-State, overlaps with Shaw's in that Levene is deeply committed to an exploration of modernity and its particular destruction of social identities, subsistence strategies, and indigenous worldviews. Of all the canonical works of genocide studies, Levene's is the most eclectic in content, apart perhaps from Ben Kiernan's Blood and Soil (2006). ${ }^{5}$ Despite Levene's commitment to a genocide-as-modernity thesis, the breadth of his analysis may leave us with a global-historical understanding of what is essentially the same phenomenon-that is, while modernity may have reconstructed the institution of genocide, it did not invent it. Nonetheless, Levene's books stand as the greatest works of genocide studies yet published. They and their successors in his four-volume project will reverberate for as long as we have a field.

With his expert grasp of Central and Eastern European dynamics of genocide in the nineteenth and twentieth centuries-captured in many of the book reviews he has published in the Journal of Genocide Research in recent years-Levene exemplifies the increasingly symbiotic relationship between genocide studies and Holocaust studies. The evolution of a comparative field of genocide studies necessarily displaced the Holocaust case from its sui generis position. But Holocaust studies remains amazingly vital today, perhaps more than ever; for that reason, most genocide scholars keep a close eye on it.

A combination of factors and a series of iconic works ${ }^{6}$ have shifted Holocaust scholars' focus, both historiographically and geographically, from the death camps and gas chambers of Poland to the killing fields of the "Holocaust by bullets" in the eastern occupied territories, notably Ukraine, Belarus, and the Baltic states. In these territories between 1941 and 1944, upwards of 1.5 million Jews were exterminated, along with millions of Soviet prisoners of war (2.8 million during an eight-month period in 1941-1942 alone). ${ }^{7}$ These mass atrocities occurred in the zone that Timothy Snyder has dubbed "the Bloodlands," in a book that has commanded considerable attention over the past year or so. ${ }^{8}$ The core framing of Snyder's book is not wholly original. The "bloodlands" that he identifies (roughly, the region between what are today eastern Poland and western Russia) were much the same borderlands and "shatter-zones" studied in the interdisciplinary Borderlands Project, sponsored by Brown University's Watson Institute beginning in 2003. The existing studies pointed to interlocking genocides and repetitive genocidal iterations-inflicted by Nazis, Soviet Communists, and miscellaneous others-during the first half of the twentieth century. But, Snyder's work, lodged with a major publisher and granted a significant publicity push, "branded" this zone of mass slaughter and helped to popularize the notion of Hitler's crimes in Europe as constituting only part of an escalating series of mass atrocities inflicted alongside those perpetrated by Stalin's USSR (and eventually in league with it). The seething cauldron of genocides in the bloodlands during the 1930s and 1940s has now been described in dozens of monographs in several languages, most of them published in the last decade. This literature will anchor the new studies of genocide in Europe during its bloodiest paroxysms from 1914 to 1945 . 


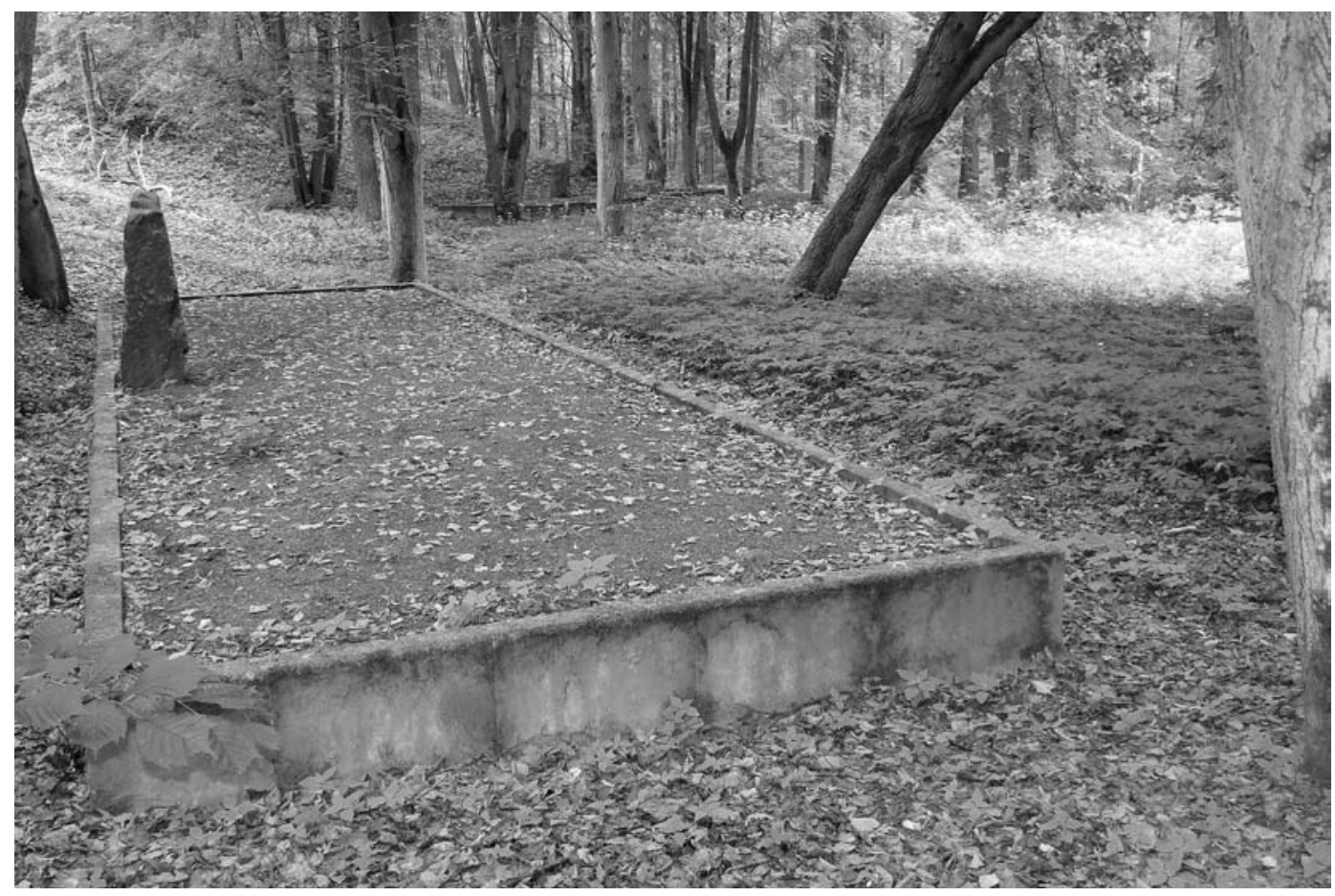

Figure 1. Mass grave of Jewish victims of the "Holocaust by bullets," in Bikernieku forest, outside Riga, Latvia (photo: Adam Jones, June 2011)

The continuing vitality of Holocaust studies also derives from the links forged with a dominant trend in genocide studies over the last decade or two. I refer to the growing inclusion of native peoples and indigenous genocides-not merely as contributions to the case-study literature, but as foundational to understandings of genocide in the modern (post-1492) period. To Raphael Lemkin's credit, the more we learn about his genocide research, the more we gain an understanding of his deep empathy for indigenous peoples who were trampled and destroyed by Western colonialism; among the first generation of comparative genocide scholars, Colin Tatz's contributions also stand out. ${ }^{9}$ The quincentenary in 1992 of the colonization of the western hemisphere spawned a set of important works by David Stannard, Ward Churchill, Richard Drinnon, Russell Thornton, and others. ${ }^{10}$ A qualitatively new stage of analysis was reached with works linking indigenous genocides to the unfolding of the Nazi Holocaust in the east-against the "redskins" and "barbarians" that Hitler and his henchmen identified and targeted (citing the American "clearing" of the Great Plains as inspiration). A proposed "missing link" in the chain, and the subject of much recent study, was the German genocide in South-West Africa, waged against the Herero and Nama peoples between 1904 and 1907. There was a notable overlap between some leading German South-West African personnel (administrators, ideologues, and pseudo-scientists) and those prominent in the early stages of the Nazi movement. Likewise, the death camps of Europe, or at least the Nazi slave-labor camps, seem presaged by Shark Island and the other now-notorious killing grounds of Namibia's native people. 
Whether or not strong connections between these two eras of German expansionism are accepted, the understanding that Hitler saw his eastern conquests in rather traditional imperial terms is now held by many scholars (among the most significant are A. Dirk Moses, Dominik Schaller, Jürgen Zimmerer, Ann Curthoys, and Benjamin Madley). ${ }^{11}$ This emphasis on the holocausts of Western colonialism may well prove the most prominent theme in the literature in the coming years.

Mention of the Namibian genocide reminds us of an enduring project of genocide studies: the unearthing of little-known, often conveniently forgotten atrocities from the past. (The bloodlands/borderlands literature is relevant here as well.) It is my view that a kind of Hippocratic oath should prevail in our field, proclaiming the right of all victims and survivors of genocide to receive due consideration and concern. Apart from extensive work on the Namibian genocide, we have benefited from important investigations of cases as diverse as Patagonia, Tasmania, East Timor, Circassia / the Caucasus, and North America. Madley, for example, is not only unveiling the full dimensions of the Yuki and Tolowa genocides of the nineteenth century but charting a US-wide record of the massacre of native populations. His work shows not only how case studies are proliferating but how the genocidal record is deepening in its regional and local dimensions. To this trend should be added a reframing of the "classic" genocides—not just the understanding of the Holocaust as colonialism, already noted, but the reconfiguring of the Armenian Genocide as one of a number of intertwined anti-Christian genocides under the Ottoman Empire and the growing study of the Rwandan Genocide in a regional and macro-historical context. ${ }^{12}$

Do these investigations truly hew to the Hippocratic ideal? Are all victims and survivors receiving their due? To a considerable degree, I think the answer is yes. Genocide scholars, beginning with Lemkin himself, have been extraordinarily open to a geographically and historically broad framing of genocide. But until very recently it was a geographically narrow range of scholars-mostly North American, Western European, and Australasian-who generated the vast majority of academic contributions. Journalistic and public discussion of genocide has likewise been heavily concentrated in the developed West. It is questionable how much this has changed in the last decade or two, but there is certainly a resurgence evident in the UK / Western European / Australasian nexus, centered on INoGS and its Journal of Genocide Research. ${ }^{13}$ The introduction of a distinct "Argentinian school," spearheaded by Daniel Feierstein and his colleagues in Buenos Aires, has significantly influenced the discussion of genocide and modernity, as well as making a strong case for Argentina under the junta (1976-1983) as a case of genocide. ${ }^{14}$ Several African and AfricanAmerican scholars, including Mahmood Mamdani, Charles Mironko, and Chile EboeOsuji, have made prominent contributions ${ }^{15}$; Bosnian scholars and activists were decisive in shaping the content of the 2007 IAGS conference in Sarajevo.

Overall, though, it must be acknowledged that a gulf exists between the globalhistorical reach of genocide studies as an intellectual project and its geographical reach as a field. One can hope that as interest in the subject spreads further in Latin America (including Brazil and Mexico), and as scholars in the Global South increasingly assert themselves, we will see more of the internationalization of the discussion that the field requires.

Will we also hear more female voices? Several have been foundational to our field and to closely related ones. Best known is Hannah Arendt, with the controversy evoked by her Eichmann in Jerusalem and, more recently, the attention paid to her groundbreaking study of Nazism as a culmination of Western imperialism, The Origins 
of Totalitarianism. ${ }^{16}$ Probably no book in the history of genocide studies has been more widely read, and more influential on the policy front, than Samantha Power's $A$ Problem from Hell. ${ }^{17}$ Helen Fein's contributions over many years are also significant; while Barbara Harff, in cooperation with Ted Gurr, has published a number of canonical and methodologically rigorous studies. ${ }^{18}$ Analyses of gender and genocide have established Joan Ringelheim and Elisa von Joeden-Forgey as influential figures. ${ }^{19}$

One hopes that a greater gender balance will also soon be evident in an institutional sense. The ballot for the latest (2011) elections for the IAGS executive featured no woman candidate above the (lowest) level of the Advisory Council. The other leading scholarly grouping, the INoGS, is likewise something of a boys' club. The executives of both scholarly journals in the field display a similar pattern, though both have been commendably open to female contributors. Overall, the unusually diffuse and eclectic character of genocide studies as an intellectual enterprise contrasts strongly with its still rather staid and traditional professional structure.

Fortunately, there seems no sign that another of the field's key attributes, its remarkable disciplinary pluralism, is ebbing. This was evident from the start, in Raphael Lemkin's field-defining blend of historical, anthropological, legal, and philosophical strains, overlaid with a moral-entrepreneurial stance. The tendency in genocide studies since its "rebirth" in the late 1970s is to draw ever-wider circles of academics and individuals into the discussion. From an initial array of historians, legal scholars, sociologists, political scientists, and psychologists, genocide scholarship has moved to absorb influences from anthropology, cultural studies, indigenous studies, gender studies, and moral philosophy, to cite only a few. Artists, poets, and playwrights have also moved to the fore, and now we see the natural sciences beginning to assume greater prominence, with the high profile accorded to forensic investigations and exhumations of genocide victims ${ }^{20}$ as well as Russell Schimmer's recent application of remote-sensing satellite technologies to genocide prevention and intervention. ${ }^{21}$

One inevitable result of this laudable "all hands on deck" approach is that it leaves the field in a constant state of evolution, exploration-and confusion. Sometimes the proliferation of alternative definitions of "genocide" seems almost surreal (I include literally dozens of examples, spread over three and a half pages, in my genocide textbook). I think we had better accept that genocide will forever be an "essentially contested concept." Yet it remains one that can spur individuals to outrage and action, bind together a diverse and diffuse community of knowledge and practice, and underpin an (albeit weak) prohibition regime. Aside from being inevitable and probably perpetual, the definitional and conceptual debates may actually help to keep people more honest and modest. With no "school" of genocide studies really dominant (or aggressively pushed, à la "rational choice" in political science), egos are likelier to be checked at the door. There is less rivalry and oneupmanship in genocide studies than in some other academic fields I have known.

In closing, let me stress a final inclusive aspect of our field: its activist and praxis-oriented component, which has been present from the outset and is today more powerful than ever. In this globalized age, genocide scholars are increasingly likely to mix with representatives of intergovernmental and non-governmental organizations (IGOs and NGOs, respectively), peacekeepers, religious representatives, and media and cultural figures, all commingling in real-world projects of genocide prevention and intervention. This is something to be praised and promoted.

In the days before I wrote this piece, I was contracted by the United Nations to deliver seminars to IGO and NGO personnel in Sarajevo and Geneva. David Simon of Yale was my co-presenter for a series supervised by Norul Mohamed Rashid of the 


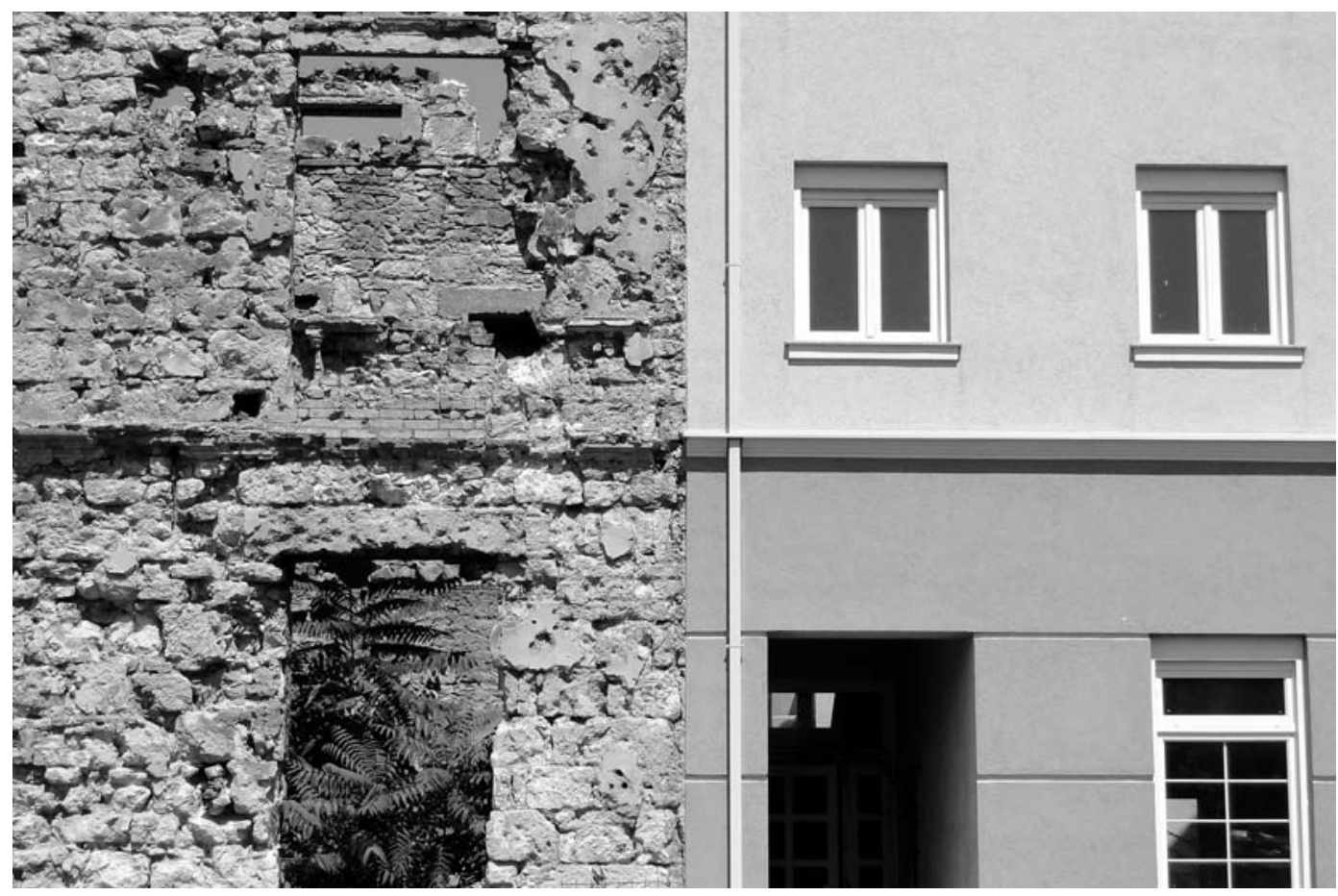

Figure 2. Ruins from the ferocious 1993-95 Croat-Bosniac conflict in the Bosnian city of Mostar, seamlessly joined to a new apartment block (photo: Adam Jones, June 2011)

UN Office of the Special Adviser on the Prevention of Genocide (OSAPG). I learned from Norul that a number of other genocide scholars have recently participated in similar OSAPG-sponsored projects, in locations such as Juba (South Sudan), Kyrgyzstan, Cambodia, Bogotá, and New York City, where the UN Special Adviser, Francis Deng, has his office. Sometimes these delegations have featured a factfinding and report-drafting component, which strikes me as another important contribution that scholars can make to the work of international organizations. ${ }^{22}$

The UN's genocide-prevention office is currently being restructured to encompass the Responsibility to Protect (R2P), a concept and political initiative that likewise typifies the closer relationship between academics and practitioners. R2P arose from a Canadian-government-sponsored project that solicited input from scholars, politicians, and field workers; it has since R2P been closely associated with the Montreal Institute for Genocide and Human Rights Studies (MIGS) and work there by Frank Chalk and his colleagues on generating a corresponding "Will to Intervene" (W2I). For my part, the opportunity to move formally and informally in UN circles helped me to discern where the current "best practice" lies in the humanitarian sphere. I also learned more about the political constraints that hamper international organizations, keeping enforcement of the Genocide Convention relatively weak. As a scholar, I felt that my own contributions were heard, respected, and perhaps even learned from by those on the front lines of the genocide-prevention endeavor.

Such interweavings of academic expertise and international organizations will increase in coming years, perhaps exponentially. We genocide scholars and students should honor the legacy of our field's founder, Raphael Lemkin, who cultivated links 
with national and international practitioners and thereby founded his enterprise in a broader community of action. The torrent of scholarly literature in recent years seems to be settling back to a more manageable flow-so let us nurture these institutional linkages, perhaps above all, in the coming years. Lemkin knew, and those who have inherited his mantle also know, that the main task is to defuse genocide-not merely to diffuse genocide studies.

\section{Notes}

1. Editors' Note: GSP has had, and continues to have, editorial advisors based in Australia, Argentina, Cambodia, Denmark, England, Ireland, the Netherlands, Rwanda, and Scotland. Contributing authors have hailed from Argentina, Australia, Belgium, Bosnia-Hercegovina, Canada, Denmark, England, France, Germany, Greece, Ireland, the Netherlands, and Sweden.

2. Mark Levene, Genocide in the Age of the Nation-State, vol. 1, The Meaning of Genocide, and vol. 2, The Rise of the West and the Coming of Genocide (London: I.B. Tauris, 2005); Martin Shaw, What Is Genocide? (London: Polity, 2007).

3. On a visit to the Newark campus of Rutgers University in spring 2011, I learned of anthropology professor and genocide scholar Alex Hinton's coordination of a team of undergraduate and graduate students, all of them conducting original research on Lemkin's writings in the archives held by the New York Public Library. For another example of a return to Lemkin's more cultural/social framing of genocide see Kurt Mundorff, "Other Peoples' Children: A Textual and Contextual Interpretation of the Genocide Convention, Article 2(e)," Harvard International Law Journal 50, no. 1 (2009): 61-128.

4. Adam Jones, Genocide: A Comprehensive Introduction, 2nd ed. (London: Routledge, 2010), 29-33.

5. Ben Kiernan, Blood and Soil: A World History of Genocide and Extermination from Sparta to Darfur (New Haven, CT: Yale University Press, 2007).

6. Looking back, whatever else one wishes to say of it, Daniel Jonah Goldhagen's Hitler's Willing Executioners: Ordinary Germans and the Holocaust (New York: Vintage, 1997) was nothing short of gut-wrenching in its depiction of the up-close mass killings of Jews on the eastern front. With the debate between Goldhagen and Christopher Browning, Ordinary Men: Reserve Police Battalion 101 and the Final Solution in Poland (New York: Perennial, 1993) over perpetrator motivations now cooled, we can perhaps recognize Browning's volume (and his work overall) as more seminal and convincing. But Goldhagen's more confrontational approach, and the near-prophetic blaze of his prose, exerted an influence that still lingers. See also Robert R. Shandley, ed., Unwilling Germans? The Goldhagen Debate (Minneapolis: University of Minnesota Press, 1998).

7. Catholic priest Patrick Desbois's activism and "honest witnessing," as a forensic documenter of the "Holocaust by bullets" in Ukraine and Belarus, is Nobel Prize-worthy and should be acknowledged here. See Patrick Desbois, The Holocaust by Bullets: A Priest's Journey to Uncover the Truth behind the Murder of 1.5 Million Jews (London: Palgrave Macmillan, 2008).

8. Timothy Snyder, Bloodlands: Europe between Hitler and Stalin (New York: Basic Books, 2010).

9. Many of Tatz's important essays are compiled in With Intent to Destroy: Reflections on Genocide (New York: Verso, 2003).

10. David E. Stannard, American Holocaust: The Conquest of the New World (New York: Oxford University Press, 1992); Ward S. Churchill, A Little Matter of Genocide: Holocaust and Denial in the Americas, 1492 to the Present (San Francisco: City Lights, 1997); Richard Drinnon, Facing West: The Metaphysics of Indian Hating and Empire Building (New York: Schocken, 1990); Russell Thornton, American Indian Holocaust and Survival: A Population History since 1492 (Norman: University of Oklahoma Press, 1990). 
11. See, e.g., A. Dirk Moses, ed., Empire, Colony, Genocide: Conquest, Occupation, and Subaltern Resistance in World History (New York: Berghahn, 2008); Jürgen Zimmerer, "The Birth of the 'Ostland' Out of the Spirit of Colonialism: A Postcolonial Perspective on Nazi Policy of Conquest and Extermination," Patterns of Prejudice 39, no. 2 (2005): 197-219; Ann Curthoys, "Raphaël Lemkin's 'Tasmania': An Introduction," Patterns of Prejudice 39, no. 2 (2005): 162-69; Benjamin Madley, "From Africa to Auschwitz: How German South West Africa Incubated Ideas and Methods Adopted and Developed by the Nazis in Eastern Europe," European History Quarterly 35, no. 3 (2005):429-64.

12. Something of this reframing trend is conveyed by separate editions of my textbook, chapter 4 of which evolved from "The Armenian Genocide" in the first edition to "The Ottoman Destruction of Christian Minorities" in the second, to give due consideration to the other Christian groups (Pontian and Anatolian Greeks, Assyrians) swept up in the Ottoman holocaust. This reframing was buttressed by the decision of the IAGS to officially recognize the Greek and Assyrian genocides alongside the Armenian one, in a resolution passed in December 2007 (see http://www.notevenmyname.com/9.html). For the third edition of Genocide: A Comprehensive Introduction, I plan to replace the Rwandan Genocide chapter with a chapter titled "Genocide in the African Great Lakes Region," covering 1959 to the present, to do greater justice to the regional interweaving of ethnicities and genocidal atrocities over several decades.

13. Editors' Note: The same is true, but in a different way, of the IAGS and its flagship journal, $G S P$, which began with a US/Israel nexus but have now expanded to span the United States, Israel, the United Kingdom, Western Europe, Australia, and South America. Tellingly, a recent issue of GSP was co-edited by Argentinian scholar and current IAGS First Vice-President Daniel Feierstein.

14. See especially Daniel Feierstein, El genocidio como práctica social: Entre el nazismo y la experiencia argentina (Buenos Aires: Fondo de Cultura Económica, 2007); Daniel Feierstein, ed., Terrorismo de Estado y genocidio en América Latina (Buenos Aires: Prometeo, 2009).

15. Mahmood Mamdani, When Victims Become Killers: Colonialism, Nativism, and the Genocide in Rwanda (Princeton, NJ: Princeton University Press, 2001); Charles K. Mironko, "Ibitero: Means and Motive in the Rwandan Genocide," in Genocide in Cambodia and Rwanda: New Perspectives, ed. Susan E. Cook (New Brunswick, NJ: Transaction Publishers, 2005); Chile Eboe-Osuji, "Rape as Genocide: Some Questions Arising," Journal of Genocide Research 9 (2007): 251-73.

16. Hannah Arendt, Eichmann in Jerusalem: A Report on the Banality of Evil (New York: Viking, 1965); Arendt, The Origins of Totalitarianism, new ed. (New York: Harcourt, 1968). See also Richard H. King and Dan Stone, eds., Hannah Arendt and the Uses of History: Imperialism, Nationalism, Race and Genocide (New York: Berghahn, 2007).

17. Samantha Power, "A Problem from Hell": America and the Age of Genocide (New York: Basic Books, 2002).

18. Helen Fein, Genocide: A Sociological Perspective (London: Sage, 1993); Fein, Human Rights and Wrongs: Slavery, Terror, Genocide (New York: Paradigm, 2007); Barbara Harff, "No Lessons Learned from the Holocaust? Assessing Risks of Genocide and Political Mass Murder since 1955," American Political Science Review 97, no. 1 (2003): 57-73; Barbara Harff and Ted Gurr, "Assessing Country Risks of Genocide and Politicide in 2009," http://www.genocidewatch.org/images/ArticlesOnGenocide_Assessing_country_risks_ of_genocide_and_politicide_in_2009.doc.

19. See, e.g., Joan Ringelheim, "Genocide and Gender: A Split Memory," in Gender and Catastrophe, ed. Rohit Lentin, 18-35 (London: Zed Books, 1997); R. Charli Carpenter, "Innocent Women and Children": Gender, Norms and the Protection of Civilians (London: Ashgate, 2006); Elisa von Joeden-Forgey, "Gender and Genocide," in The Oxford Handbook of Genocide Studies, ed. Donald Bloxham and A. Dirk Moses (Oxford: Oxford University Press, 2010).

20. For information on the important work of the International Commission on Missing Persons (ICMP) see their Web site at http://www.ic-mp.org/. 
21. Russell Schimmer, "Tracking Evidence of Genocide through Environmental Change: How Remote Sensing Can Be Applied to the Study of Genocide," in New Directions in Genocide Research, ed. Adam Jones (London: Routledge, 2011).

22. We can also stage important interventions, as scholars, in cases of what I call "egregious" genocide denial. In the past year, along with Gerald Caplan, I found myself swept up in one such campaign, to counter Edward S. Herman and David Peterson's denial of the 1994 Rwandan Genocide in their book The Politics of Genocide (New York: Monthly Review Press, 2010). See Gerald Caplan, "The Politics of Denialism: The Strange Case of Rwanda," Pambazuka 486 (17 June 2010), http://www.pambazuka.org/en/category/ features/65265 (accessed 4 October 2011); Adam Jones, "Denying Rwanda: A Response to Herman \& Peterson," http://www.genocidetext.net/denying_rwanda.html (accessed 4 October 2011). Both were cited as "expert" support by Guardian columnist George Monbiot, staging what stands at the time of writing as the only mainstream press intervention on the subject: Monbiot, "Left and Libertarian Right Cohabit in the Weird World of the Genocide Belittlers," The Guardian, 13 June 2011, http://www.guardian.co.uk/ commentisfree/2011/jun/13/left-and-libertarian-right (accessed 4 October 2011); see also Monbiot's letter to MediaLens, http://www.monbiot.com/2011/06/17/do-as-we-say-not-aswe-do-2/ (accessed 4 October 2011). It is discouraging to have to devote time to countering genocide denial in the public sphere, but it is our duty, and our privilege, to do so. 